\title{
Classification of ticks collected from horses in the Netherlands in 2008-2009 and identification of the (zoonotic) agents they contain
}

\author{
Catherine M. Butler 1,2, Marianne M. Sloet van Oldruitenborgh-Oosterbaan', Tom A. E Stout ',3, Frans Jongejan ${ }^{4,5}$, Arno H. Werners ${ }^{6}$ \\ and Dirk J. Houwers ${ }^{7}$ \\ 1 Department of Equine Sciences, Faculty of Veterinary Medicine, Utrecht University, Utrecht, the Netherlands \\ 2 Large Animal Medicine and Surgery Department, School of Veterinary Medicine, St. George's University, True Blue, Grenada, West-Indies \\ 3 Department of Production Animal Sciences, Faculty of Veterinary Science, University of Pretoria, Onderstepoort, South Africa \\ 4 Utrecht Centre for Tick-borne Diseases, Faculty of Veterinary Medicine, Utrecht, University, Utrecht, the Netherlands \\ 5 Department of Veterinary Tropical Diseases, Faculty of Veterinary Science, University of Pretoria, Onderstepoort, South Africa \\ 6 Anatomy, Physiology and Pharmacology Department, School of Veterinary Medicine, St. George's University, True Blue, Grenada, West-Indies \\ 7 Veterinary Microbiological Diagnostic Centre, Department of Infectious Diseases and Immunology, Faculty of Veterinary Medicine, Utrecht University, Utrecht, \\ the Netherlands
}

Summary: This study shows which hard tick species (Ixodidae) were found on domestic horses in the Netherlands in 2008-2009, and what potential pathogens these ticks carried. In the period 2008-2009, 130 ticks were collected, classified and screened for the presence of DNA from specific tick-borne pathogens using PCR-RLB. The numbers of ticks of the various species found were: 68 Ixodes ricinus, 58 Ixodes spp. (57 nymphs and 1 larva), 2 Dermacentor reticulatus and 2 Hyalomma marginatum. DNA from Borrelia valaisiana was detected in $49 \%$ of these ticks, B. afzelii in 22\%, B. burgdorferi sensu stricto and B. garinii in 3\% and 2\%, respectively. Rickettsia helvetica was detected in $9 \%$ of examined ticks, Anaplasma phagocytophilum in $1.5 \%$, Babesia venatorum in $4 \%$, and B. caballi and Theileria equi in 1.5 and $3 \%$, respectively. There were considerable regional differences suggesting focal distribution of these potential pathogens.

Keywords: tick, horse, PCR-RLB, zoonotic, emerging, Borrelia, Anaplasma, Babesia, Rickettsia, Ehrlichia

Citation: Butler C. M., Sloet van Oldruitenborgh-Oosterbaan M. M., Stout T. A. E, Jongejan F., Werners A. H., Houwers D. J. (2016) Classification of ticks collected from horses in the Netherlands in 2008-2009 and identification of the (zoonotic) agents they contain. Pferdeheilkunde 32, 329-334

Correspondence: Prof. Marianne Sloet van Oldruitenborgh-Oosterbaan, Department of Equine Sciences, Faculty of Veterinary Medicine, Utrecht University, Yalelaan 112,3584 CM Utrecht, the Netherlands; E-mail: m.sloet@uu.nl

\section{Introduction}

Ticks play a significant role as vectors of several bacterial, protozoal and viral pathogens of worldwide human medical, veterinary and economic importance (de la Fuente et al. 2008, Jongejan et al. 2004). Among the various species of hard ticks endemic to Western Europe, Ixodes ricinus is the most frequently found (Stanek et al. 2004). In the Netherlands, lxodes ricinus is the predominant species recovered from domestic animals (Nijhof et al. 2007) and is the most important vector of a number of emerging pathogens of veterinary and medical significance, including Borrelia burgdorferi sensu lato, Babesia spp., and Ehrlichia-Anaplasma spp. (Estrada-Pena et al.1999). Like other Ixodid ticks, I. ricinus' developmental cycle includes four stages (egg, larva, nymph, adult) and takes 2-3 years to complete (Sonenshine et al. 1991). At each stage, the tick needs a blood meal in order to develop to the next stage and therefore has to find a new host. Consequently, ticks are an important means of transmitting blood or skin borne pathogens between hosts. Adult ticks feed mainly on large mammals such as cattle, sheep and deer, whereas larvae and nymphs usually feed on small- and medium-sized vertebrates (Sonenshine et al. 1991).

Although studies on the prevalence of tick-borne pathogens in tick vectors (Ferquel et al. 2006, Reye et al. 2010, Wielinga et al. 2009, Wielinga et al. 2006, Hartelt et al. 2008), and vertebrate hosts (Nijhof et al. 2007, Lommano et al. 2012, Passamonti et al. 2010) in the Netherlands and other North-Western European countries have been performed, there is little data on the classification and the frequency of the various tick species that infest horses or of the prevalence of significant pathogens in these ticks.

Horse numbers have increased in the Netherlands over the last 2 decades, with the horse becoming an ever-more popular recreational or "companion animal". In this respect, horses are considered to share their owners' biotope, at least with respect to tick exposure, even more than dogs which tend to have more intense contact with low growing shrubs. Ticks from horses may be regarded as excellent sentinels for tickborne infections of zoonotic significance. In recent years, there has been evidence of the spread of tick species into areas where they were previously unable to survive year-round, probably as a result of climate change; this spread of tick species into new areas has been accompanied by a parallel spread in tick-borne pathogens across areas of Western Europe previously considered free of endemic disease (Nijhof et al. 2007, Estrada-Pena 2012).

This study aimed to investigate the distribution and types of ticks specifically collected from horses in the Netherlands and to determine the proportion of these ticks that carried not only the known equine pathogens Borrelia burgdorferi sensu lato 
spp., Theileria equi, Babesia caballi, and Anaplasma phagocytophilum, but also other agents of potential medical/veterinary importance that have been identified previously in Europe, including Babesia divergens, Babesia bovis, Babesia microti, Babesia venatorum, Babesia canis, Rickettsia helvetica, Ehrlichia schotti, and Anaplasma marginale.

\section{Materials and methods}

Study design and tick collection

Equine practitioners in the Netherlands were contacted early in 2008 by the Utrecht Centre for Tick-borne Diseases (UCTD) with a request to submit ticks recovered from horses. Of the ticks submitted between May 2008 and September 2009, a total of 130 from 56 horses belonging to 50 different owners were identified to species level, together with developmental stage and gender, using standard keys (Estrada-Pena 2004). The ticks were then fixed and stored in $70 \%$ ethanol prior to subsequent screening for specific pathogens using polymerase chain reaction- reverse line blot (PCR-RLB). Forty-seven of the 56 horses were also included in a prospective study examining clinical and diagnostic aspects of $B$. burgdorferi and $A$. phagocytophilum infections following a known tick-bite (Butler et al. 2016).

Classification and determination of sex and developmental stage

Ticks were classified using standard keys (Estrada-Pena 2004) and categorized as larvae, nymphs, adult females or adult males.

DNA extraction and PCR-RLB for specific pathogen detection

DNA was extracted from the ticks using the Nucleospin Tissue kit (Macherey-Nagel, Düren, Germany) following the manufacturer's instructions for the extraction and purification of genomic DNA from insects. Previously validated PCR primer pairs for the detection of Borrelia, Anaplasma, Ehrlichia, Rikkettsia, Theileria and Babesia DNA were used to detect the major groups of pathogens via a PCR-assay using an automated thermocycler (Bio-Rad Laboratories, Veenendaal, the Netherlands) as described previously (Bekker et al 2008, Nijhof et al. 2005, Schouls et al. 1999). Subsequently, the PCR products generated were applied to an RLB hybridization blot prepared with specific probes for the agents $B$. burgdorferi sensu lato (four genospecies), T. equi, B. caballi, A. phagocytophilum, $B$. divergens, $B$. bovis, $B$. microti, $B$. venatorum, $B$. canis, $R$. helvetica, E. schotti and $A$. marginale, as described by Nijhof et al. (2005). Positive control-DNA for each specified agent was included in each test run.

\section{Results}

Tick species, developmental stages and gender

Of the 130 ticks examined, 68 were classified as adult I. ricinus (63 females and 5 males), 58 were immature Ixodes spp
(57 nymphs and 1 larva), 2 were classified as adult female $D$. reticulatus, and 2 as adult female $H$. marginatum. All ticks were further processed for detection of DNA for the pathogens of interest.

\section{Detection of DNA for tick-borne pathogens using PCR-RLB}

The results of the PCR-RLB are summarized in Table 1. DNA from the pathogens of interest was detected in 95 (73\%) of the 130 ticks examined. Borrelia spp. were the most commonly detected pathogens and were recovered from 72 ticks of which 28 were co-infected with 2 or more species (Table 1). The incidence of pathogen DNA was similar between adult ticks and nymphs. The geographical distribution of the various pathogens is depicted in Figure 1. The distribution of pathogens differed between regions, most strikingly for Theileria equi (and the Theileria equi-like pathogens), which were detected in only one area in the south of the country.

\section{Discussion}

Following a request to Dutch equine practitioners early in 2008 to submit ticks collected from horses, a total of 130 ticks were submitted by the end of 2009; these were classified and subjected to PCR-RLB for detection of potential pathogens. The majority of ticks were classified as Ixodes spp, as was the

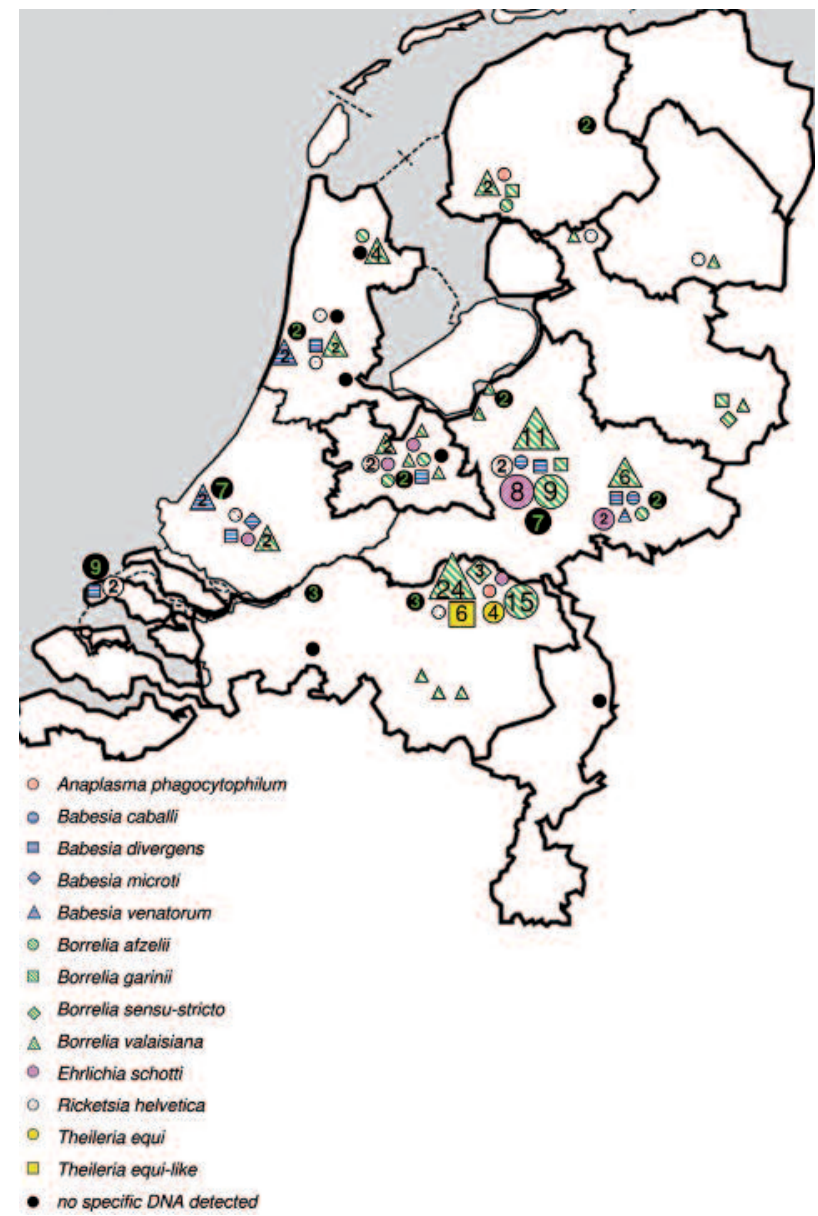

Fig. 1 Geographic distribution of the number of ticks with DNA from specific agents per region or location of collection (if no number is indicated it is 1). 
case for previous studies of ticks collected from other (nonequine) host species in this part of Europe (Nijhof et al 2007, Jaenson et al. 2012, Pavlidou 2008). That $40 \%$ of collected ticks were nymphs was surprising in given that nymphs (and larvae) are generally considered to feed primarily on small and medium sized mammalian hosts (Sonenschein 1991). This suggests either that horses are actually a preferred host for lxodes nymphs, or that suitable small mammal hosts were insufficiently available in the habitat where these horses acquired the ticks. The finding of two adult $D$. reticulatus is in line with recent reports that this tick species has become established in the Netherlands (Nijhof et al. 2007). The two adult specimens of $H$. marginatum are also noteworthy; they were recovered from horses living more than 100 kilometers apart from each other along the eastern border of the Netherlands. Hyalomma spp are regarded as non-indigenous to Western Europe, so whether they were incidental drop-offs from migrating birds or early signs of establishment of a permanent population remains to be seen. Only the larval and nymph stages of Hyalomma feed on birds, therefore the fact that the Hyalomma ticks recovered were adults suggests that the weather conditions along the eastern border of the Netherlands allowed the moulting of Hyalomma. Establishment of this tick species in virgin areas could potentially have serious consequences given that it is a vector of Crimean-Congo haemorrhagic fever virus (Zeller et al. 1994), an important pathogen in man, and probably also of West Nile virus, a pathogen of clinical importance in both man and horses (Chevalier et al. 2004, Formosinho et al. 2006).

The geographic distribution of the submitted ticks is depicted in Fig 1. The clustering, however, is most likely in part a consequence of sampling bias: as a result of the voluntary study design, it is likely that some equine practitioners were simply more active in collecting and submitting ticks than others. The distribution of DNA from specific pathogens in the ticks also indicates regional differences in the distribution of these agents. This underlines the complex dynamics of ticks and the complicated dynamics and epidemiology of tick-borne infections.

The results for the incidence of Borrelia-DNA detection in 120 of the 130 ticks reported in the current article are discussed in the parallel article on horse and tick infection with Borrelia and $A$. phagocytophilum (Butler et al. 2016); the 10 extra tikks do not alter the general picture that $B$. valaisiana and $B$. afzelii were the most prevalent species and $B$. burdorferi sensu stricto much less common. The potential consequences in terms of clinical borreliosis are discussed in the other article, as are the implications of detecting $A$. phagocytophilum in two I. ricinus ticks (1.5\%).

The recovery from the ticks of DNA from several Babesia spp. (B. venatorum (B EU1), $B$ divergens, B. microti and B. caballi) and $R$. helvetica is interesting because all have been reported previously in the Netherlands, in ticks collected from the vegetation (Wielinga et al. 2009) and dogs (Nijhof et al. 2007). Moreover, all are reported to be pathogenic to man. In particular, B. venatorum, $B$. divergens and B. microti are capable of causing human babesiosis (Gray et al. 2006, Herwaldt et al 2003). Indeed, most documented human cases of babesiosis are caused by $B$. divergens (Vannier and Krause 2009), a pathogen that was present in 6/130 (4.6\%) of the ticks removed from horses, and which is a higher percentage than previously reported in the Netherlands or other Western European countries (Niihof et al. 2007, Wielinga 2009, Duh et al. 2009, Capelli 2012). This suggests that the risk of human babesiosis may be increasing. With regard to another zoonotic pathogen, $R$. helvetica, DNA was detected in 12 (9\%) of the collected ticks. R. helvetica infection in people is associated with a mild flu-like disease (Fournier et al. 2004), although chronic infections have been proposed to play a

\begin{tabular}{|c|c|c|c|}
\hline & Nymph & Adult female & Adult male \\
\hline Babesia caballi & 1 & 1 & 0 \\
\hline Babesia canis & 0 & 0 & 0 \\
\hline Babesia divergens & 4 & 2 & 0 \\
\hline Babesia microti & 0 & 1 & 0 \\
\hline Babesia venatorum & 3 & 2 & 0 \\
\hline Anaplasma phagocytophilum & 0 & 2 & 0 \\
\hline Ehrlichia schotti & 3 & 10 & 1 \\
\hline Borrelia afzelii & 15 & 13 & 1 \\
\hline Borrelia burgdorferi sensu stricto & 2 & 2 & 0 \\
\hline Borrelia garinii & 0 & 3 & 0 \\
\hline Borrelia valaisiana & 31 & 33 & 0 \\
\hline Rickettsia helvetica & 4 & 8 & 0 \\
\hline Theilleria equi & 2 & 2 & 0 \\
\hline Theilleria equi like & 5 & 1 & 0 \\
\hline Total & 70 & 80 & 2 \\
\hline
\end{tabular}

A total 45 of the 130 ticks were negative for DNA of the above agents and 28 ticks had co-infections with 2 or more Borrelia species:

B. valaisiana and $B$. afzelii $(\mathrm{n}=23)$

B. burgdorferi sensu stricto and $B$. garinii $(\mathrm{n}=1)$

B. valaisiana, B. afzelii and B. garinii $(\mathrm{n}=1)$ with $B$. valaisiana

$B$. afzelii and $B$. burgdorferi sensu stricto $(\mathrm{n}=3)$ 
role in sarcoidosis and chronic perimyocarditis (Nilsson et al. 1999, Nilsson et al. 2002). The prevalence of $R$. helvetica DNA in the ticks in this study (9\%) was lower than usually found in Europe (Nijhof 2007, Christova et al. 2003, Hartelt et al. 2004), although this may be a result of seasonal fluctuations or, more likely, the high percentage of nymphs recovered in the present study.

The presence of $B$. caballi DNA (2/130: $1.5 \%$ ) in one I. ricinus female and one lxodes nymph is a novel finding for the Netherlands which was considered free of this pathogen; nevertheless, the finding of $B$. caballi in ticks explains the recent description of an autochthonous case of equine babesiosis in the Netherlands (Butler et al. 2012). The two other pathogens that cause equine piroplasmosis, namely $T$. equi and T. equi-like, were also detected for the first time in lxodes ticks in the Netherlands (Table 1). Although the vector capacity of $\mathrm{I}$. ricinus for these equine pathogens has not been established, the fact the Dermacentor reticulatus is a capable vector allied to the emergence of resident Dermacentor populations, indicates that there is now appreciable risk of equine piroplasmosis in horses that have never left the Netherlands. This is a fact that equine practitioners should take into account when confronted with a horse suffering from pyrexia of unknown origin. Strikingly, the ticks containing Theileria-DNA were all from one geographical collection area (equine practice); the first autochthonous piroplasmosis cases caused by this agent also occurred in this area (Butler et al. 2012).

E. schotti DNA was detected in 14 ticks (11\%), and therefore at a slightly higher rate than the 3.4-6.8\% reported by Wielinga et al. in 2006 (Wielinga et al. 2006). In addition, the distribution of ticks containing this agent appeared to be rather focal (Fig. 1). It was recently reported that E. schotti is identical to Neoehrlichia mikurensis (Jahfari et al. 2012) and probably establishes a reservoir in small rodents; however, its pathogenic potential is not yet known.

All of the pathogens detailed were detected in both nymphs and adult ticks, with a high incidence of co-infections (Table 1). The high frequency of co-infection may be significant because it has been suggested that co-infection enhances pathogenicity of a number of tick-borne pathogens in both man and animals (Belongia 2002, Thomas et al. 2001). Serological investigations in horses as well indicated a frequent co-infection with tick-borne pathogens (Laus et al. 2013).

\section{Conclusion}

This study demonstrated that I. ricinus is the predominant tick species infesting horses in the Netherlands and, moreover, that it carries a variety of emerging (zoonotic) tick-borne pathogens; the most frequently encountered pathogen was $B$. valaisiana. The detection of a surprisingly large number of Ixodes nymphs on domestic horses is an indication that, at least in some regions of the Netherlands, tick density is relatively high; both the relatively high incidence of ticks and the range of pathogens carried have important possible implications for the risks of tick-borne infections in man, since horses appear to be excellent sentinels.

\section{Acknowledgements}

We thank the referring veterinarians and animal owners for their cooperation in submitting the ticks that made this study possible. We also thank Jesper Balk and Michiel Wijnveld for providing additional laboratory assistance.

\section{Conflict of interest statement}

None of the authors of this paper has a personal or financial relationship with other organizations or people that could inappropriately influence or bias the content of the paper.

\section{References}

Bekker C. P., de Vos S., Taoufik A., Sparagano O. A., Jongejan F. (2002) Simultaneous detection of Anaplasma and Ehrlichia species in ruminants and detection of Ehrlichia ruminantium in Amblyomma variegatum ticks by reverse line blot hybridization. Vet. Microbiol. 89, 223-238

Belongia E. A. (2002) Epidemiology and impact of coinfections acquired from Ixodes ticks. Vector Borne Zoonotic Dis. 2, 265 273

Butler C. M., Sloet van Oldruitenborgh-Oosterbaan M. M., Stout T. A., van der Kolk J. H., Wollenberg L. V., Nielen M., Jongejan F., Werners A. H., Houwers D. J. (2012) Prevalence of the causative agents of equine piroplasmosis in the South West of The Netherlands and the identification of two autochthonous clinical Theileria equi infections. Vet. J. 193, 381-385

Capelli G., Ravagnan S., Montarsi F., Ciocchetta S., Cazzin S., Porcellato E., Babiker A. M., Cassini R., Salviato A., Cattoli G., Otranto D. (2012) Occurrence and identification of risk areas of Ixodes ricinus-borne pathogens: a cost-effectiveness analysis in north-eastern Italy. Parasit. Vectors 5, 61

Chevalier V., de la Rocque S., Baldet T., Vial L., Roger F. (2004) Epidemiological processes involved in the emergence of vector-borne diseases: West Nile fever, Rift Valley fever, Japanese encephalitis and Crimean-Congo haemorrhagic fever. Rev. Sci. Tech. 23, 535-555

Christova I., Van De Pol J., Yazar S., Velo E., Schouls L. (2003) Identification of Borrelia burgdorferi sensu lato, Anaplasma and Ehrlichia species, and spotted fever group Rickettsiae in ticks from Southeastern Europe. Eur. J. Clin. Microbiol. Infect. Dis. 22, 535-542

Duh D., Petrovec M., Avsic-Zupanc T. (2001) Diversity of Babesia Infecting European sheep ticks (Ixodes ricinus). J. Clin. Microbiol. 39, 3395-3397

Estrada-Pena A., Jongejan F. (1999) Ticks feeding on humans: a review of records on human-biting Ixodoidea with special reference to pathogen transmission. Exp Appl Acarol 23, 685-715

Estrada-Pena A., Bouattour A., Camicas J.-L., Walker A. R. (2004) Ticks of domestic animals in the mediterranean region: A guide to identification of species, University of Zaragoza, Zaragoza. p 131

Estrada-Pena A., Ayllon N., de la Fuente J. (2012) Impact of climate trends on tick-borne pathogen transmission. Front. Physiol. 3, 64

Ferquel E., Garnier M., Marie J., Bernede-Bauduin C., Baranton G., Perez-Eid C., Postic D. (2006) Prevalence of Borrelia burgdorferi sensu lato and Anaplasmataceae members in lxodes ricinus ticks in Alsace, a focus of Lyme borreliosis endemicity in France. Appl. Environ. Microbiol. 72, 3074-3078

Formosinho P., Santos-Silva M. M. (2006) Experimental infection of Hyalomma marginatum ticks with West Nile virus. Acta Virol. 50, 175-180

Fournier P. E., Allombert C., Supputamongkol Y., Caruso G., Brouqui P., Raoult D. (2004) Aneruptive fever associated with antibodies to Rickettsia helvetica in Europe and Thailand. J. Clin. Microbiol. 42, 816-818

Gray J. S. (2006) Identity of the causal agents of human babesiosis in Europe. Int J Med Microbiol 296 Suppl 40, 131-136 
Hartelt K., Oehme R., Frank H., Brockmann S. O., Hassler D., Kimmig P. (2004) Pathogens and symbionts in ticks: prevalence of Anaplasma phagocytophilum (Ehrlichia sp.), Wolbachia sp., Rikkettsia sp., and Babesia sp. in Southern Germany. Int. J. Med. Microbiol. 293 Suppl 37, 86-92

Hartelt K., Pluta S., Oehme R., Kimmig P. (2008) Spread of ticks and tick-borne diseases in Germany due to global warming. Parasitol. Res. 103 Suppl 1, S109-116

Herwaldt B. L., Caccio S., Gherlinzoni F., Aspock H., Slemenda S. B., Piccaluga P., Martinelli G., Edelhofer R., Hollenstein U., Poletti G., Pampiglione S., Loschenberger K., Tura S., Pieniazek N. J. (2003) Molecular characterization of a non-Babesia divergens organism causing zoonotic babesiosis in Europe. Emerg. Infect. Dis. 9, 942-948

Jaenson T. G., Jaenson D. G., Eisen L., Petersson E., Lindgren E. (2012) Changes in the geographical distribution and abundance of the tick Ixodes ricinus during the past 30 years in Sweden. Parasit. Vectors 5, 8

Jahfari S., Fonville M., Hengeveld P., Reusken C., Scholte E.J., Takken W., Heyman P., Medlock J., Heylen D., Kleve J., Sprong H. (2012) Prevalence of Neoehrlichia mikurensis in ticks and rodents from North-west Europe. Parasit. Vectors 5, 74

Jongejan F, Uilenberg G. (2004) The global importance of ticks. Parasitology 129 Suppl, S3-14

Laus F., Veronesi F., Passamonti F., Paggi E., Cerquetella M., Hyatt D., Tesei B., Fioretti D. P. (2013) Prevalence of tick borne pathogens in horses from Italy. J. Vet. Med. Sci. 75, 715-720

Lommano E., Bertaiola L., Dupasquier C., Gern L. (2012) Infections and coinfections of questing lxodes ricinus ticks by emerging zoonotic pathogens in Western Switzerland. Appl. Environ. Microbiol. 78, 4606-4612

Nijhof A. M., Bodaan C., Postigo M., Nieuwenhuijs H., OpsteeghM., Franssen L., Jebbink F., Jongejan F. (2007) Ticks and associated pathogens collected from domestic animals in the Netherlands. Vector Borne Zoonotic Dis. 7, 585-595

Nijhof A. M., Pillay V., Steyl J., Prozesky L., Stoltsz W. H., Lawrence J. A., Penzhorn B. L., Jongejan F. (2005) Molecular characterization of Theileria species associated with mortality in four species of African antelopes. J. Clin. Microbiol. 43, 5907-5911

Nilsson K., Lindquist O., Pahlson C. (1999) Association of Rickettsia helvetica with chronic perimyocarditis in sudden cardiac death. Lancet 354, 1169-1173

Nilsson K., Pahlson C., Lukinius A., Eriksson L., Nilsson L., Lindquist O. (2002) Presence of Rickettsia helvetica in granulomatous tissue from patients with sarcoidosis. J. Infect. Dis. 185, 1128-1138

Passamonti F., Veronesi F., Cappelli K., Capomaccio S., Coppola G., Marenzoni M. L., Piergili F. D., Verini S. A., Coletti M. (2010) Anaplasma phagocytophilum in horses and ticks: a preliminary survey of Central Italy. Comp. Immunol. Microbiol. Infect. Dis. 33, 73-83

Pavlidou V., Gerou S., Kahrimanidou M., Papa A. (2008) Ticks infesting domestic animals in northern Greece. Exp. Appl. Acarol. 45, 195-198

Reye A. L., Hubschen J. M., Sausy A., Muller C. P. (2010) Prevalence and seasonality of tick-borne pathogens in questing lxodes ricinus ticks from Luxembourg. Appl. Environ. Microbiol. 76, 2923-2931

Schouls L. M., Van De Pol I., Rijpkema S. G., Schot C. S. (1999) Detection and identification of Ehrlichia, Borrelia burgdorferi sensu lato, and Bartonella species in Dutch lxodes ricinus ticks. J. Clin. Microbiol. 37, 2215-2222

Smith F. D., Ballantyne R., Morgan E. R., Wall R. (2012) Estimating Lyme disease risk using pet dogs as sentinels. Comp. Immunol. Microbiol. Infect. Dis. 35, 163-167

Sonenshine D. E. (1991) Biology of Ticks, Oxford University Press, New York. p 447

Stanek G., Gray J., Strle F., Wormser G. (2004) Lyme borreliosis. Lancet Infect. Dis. 4, 197-199

Thomas V., Anguita J., Barthold S. W., Fikrig E. (2001) Coinfection with Borrelia burgdorferi and the agent of human granulocytic ehrlichiosis alters murine immune responses, pathogen burden, and severity of Lyme arthritis. Infect. Immun. 69, 3359-3371

Vannier E., Krause P. J. (2009) Update on babesiosis. Interdiscip. Perspect. Infect. Dis. 2009, 984568
Wielinga P. R., Fonville M., Sprong H., Gaasenbeek C., Borgsteede F., van der Giessen J. W. (2009) Persistent detection of Babesia EU1 and Babesia microti in lxodes ricinus in the Netherlands during a 5-year surveillance: 2003-2007. Vector Borne Zoonotic Dis. 9, 119-122

Wielinga P. R., Gaasenbeek C., Fonville M., de Boer A., de Vries A., Dimmers W., Akkerhuis Op Jagers G., Schouls L. M., Borgsteede F., van der Giessen J. W. (2006) Longitudinal analysis of tick densities and Borrelia, Anaplasma, and Ehrlichia infections of Ixodes ricinus ticks in different habitat areas in The Netherlands. Appl. Environ. Microbiol. 72, 7594-7601

Zeller H. G., Cornet J. P., Camicas J. L. (1994) Experimental transmission of Crimean-Congo hemorrhagic fever virus by west African wild ground-feeding birds to Hyalomma marginatum rufipes ticks. Am. J. Trop. Med. Hyg. 50, 676-681

Erweiterte Zusammenfassung

\section{Klassifizierung von Zecken und deren zoonotischen Kei- me bei Pferden in den Niederlanden aus den Jahren 2008-2009}

Zecken spielen weltweit und speziesübergreifend eine wichtige Rolle als Vektoren für unterschiedliche Bakterien, Viren und Protozoen. In Westeuropa ist Ixodes ricinus die am häufigsten auftretende Zeckenart und diese ist verantwortlich für die Übertragung von Borrelia burgdorferi senso lato, Babesia spp. und Ehrlichia-Anaplasma spp.. Wie andere Zecken durchläuft I. ricinus in dem Entwicklungszyklus vier Stadien und dies innerhalb von 2-3 Jahren. Für diese Entwicklung ist in jedem Stadium eine Blutmahlzeit notwendig bei einem jeweils neuen Wirt. Adulte Zecken infizieren in der Regel groBe Säugetiere wie Rinder und Schafe, wogegen Larven und Nymphen bei kleinen oder mittelgroßen Wirbeltieren Blut saugen. Informationen zur Klassifizierung und Häufigkeit der unterschiedlichen Zecken-Spezies sowie zu der Prävalenz von Pathogenen in diesen Zecken sind rar. Aufgrund des Klimawandels breiten sich Zecken in Regionen aus, in welchen sie vorherig nicht das ganze Jahr überleben konnten und so auch dementsprechend eine Ausbreitung von vorherig nicht endemischen Erkrankungen auftreten kann. In dieser Studie sollte die Verteilung und Typisierung von Zecken aufgesammelt von Pferden in den Niederlanden erfolgen und ebenso erfasst werden, ob diese Zecken die Pathogene Borrelia burgdorferi sensu lato, Theileria equi, Babesia caballi,Anaplasma phagocytophilum, Babesia divergens, Babesia bovis, Babesia microti, Babesia venatorum, Babesia canis, Rickettsia helvetica, Ehrlichia schotti und Anaplasma marginale in sich tragen. Von Mai 2008 bis September 2009 wurden von Tierärzten eingesammelte Zecken eingesandt. Es handelte insgesamt um 130 Zecken von 56 Pferden. Es folgte die Bestimmung von Spezies, Geschlecht und Stadium. Die Zecken wurden in 70\%igem Ethanol fixiert und das Screening für spezifischen Pathogenen erfolgte mittels PCR-RLB. Von den 130 Zecken wurden 68 als adulte I. ricinus (63 weibliche und 5 männliche) klassifiziert, 58 waren unreife lxodes spp. (57 Nymphen und 1 Larve), 2 waren klassifiziert als adulte weibliche $D$. reticulatus und zwei als weibliche adulte $H$. marginatum. Bei $73 \%$ der Zecken wurde DNA von den oben genannten Pathogenen identifiziert. Bei 72 Zecken lag DNA von Borrelia spp. vor und von diesen Zecken waren 28 noch mit weiteren Spezies infiziert. Die Inzidenz der pathogenen DNA unterschied 
sich nicht zwischen adulten Zecken und Nymphen. Die geographische Verteilung der Pathogene unterschied sich und zwar vor allen bei Theileria equi, welche nur in einer südlichen Region des Landes nachgewiesen wurde.

Wie schon in vorherigen Studien nachgewiesen wurde der Hauptteil der Zecken als Ixodes spp. klassifiziert. Überraschenderweise waren $40 \%$ der eingesandten Zecken Nymphen, von welchen angenommen wurde, dass sie eher kleinere Säugetiere befallen. Beachtenswert ist die Klassifizierung von $D$. reticulatus und Hyalomma marginatum, was für eine aktuelle Neu-Ansiedelung dieser Zeckenarten in den Niederlanden spricht. Bei Hyalomma handelt es sich um eine Zecke, welche als Vektor für das Krim-Kongo-Fieber des Menschen und wahrscheinlich auch für das West Nile Fieber bei Mensch und Pferd von Bedeutung ist. Der Nachweis von DNA von unterschiedlichen Babesien-Spezies, welche für den Men- schen pathogen sind deutet daraufhin, dass das Risiko einer Babesiose beim Menschen ansteigt. Ein weiteres nachgewiesenes zoonotisches Pathogen war R. Helvetica (9\%). Zum ersten Mal wurde DNA von B. caballi, T. equi und $T$. equil90lik in Ixodes-Zecken bei Pferden in den Niederlanden nachgewiesen. Da Dermacentor reticulatus - ein Vektor für die Piroplasmose - nachgewiesen wurde, sollte bei Pferden mit Fieber unbekannter Genese diese Infektion in Betracht gezogen werden. Die Ergebnisse dieser Studie zeigen, dass I. ricinus in den Niederlanden die am häufigsten auftretende Zecken-Spezies ist und dass diese Zecken eine Reihe zum Teil zoonotischer Pathogene in sich tragen. Des Weiteren wurde eine überraschend hohe Anzahl von Nymphen von den Pferden abgesammelt.

Schlüsselwörter: Zecke, Pferd, PCR-RLB, Zoonose, Borrelia, Anaplasma, Babesia, Rickettsia, Ehrlichia 